\title{
CORRECTION OF COGNITIVE ACTIVITY OF YOUNGER SCHOOLCHILDREN WITH MENTAL DISORDERS IN MATHEMATICS LESSONS IN THE SYSTEM OF INCLUSIVE EDUCATION
}

\author{
КОРЕКЦІЯ КОГНІТИВНОЇ ДІЯЛЬНОСТІ МОЛОДШИХ ШКОЛЯРІВ \\ ІЗ ПСИХІЧНИМИ РОЗЛАДАМИ НА УРОКАХ МАТЕМАТИКИ \\ В УМОВАХ ІНКЛЮЗИВНОЇ ОСВІТИ
}

УДК 376.42

DOI https://doi.org/10.32843/2663-

6085.2019.12-2.15

\section{Ilchenko O.V.,}

Candidate of Pedagogical Sciences, Associate Professor,

Assistant Professor at the Department Correctional Education

and Special Psychology

of the Communal Institution Kharkiv

Humanitarian Pedagogical Academy of the Kharkiv Regional Council

\section{Tarasova V.V.,}

Candidate of Pedagogical Sciences, Associate Professor,

Associate Professor at the Department Correctional Education

and Special Psychology

of the Communal Institution Kharkiv Humanitarian Pedagogical Academy of the Kharkiv Regional Council

Yatsinik A.V.,

Candidate of Pedagogical Sciences, Lecturer at the Department Correctional Education and Special Psychology of the Communal Institution Kharkiv Humanitarian Pedagogical Academy of the Kharkiv Regional Council
The consolidation of the inclusive education at the state level and the active implementation of its foundations in the educational process require significant changes in approaches to the content and organization of learning, in the use of didactic methods and techniques. The main task of inclusive education is to provide equal opportunities for education to all individuals, regardless of their physical and psychological characteristics. But the learning process itself must be constructed taking into account the characteristics of each of its participants. Domestic and foreign specialists include violations of the intellectual, psycho-emotional and psychic sphere, as well as children with learning difficulties and autism spectrum disorders into the list of mental disorders. Teaching children with peculiarities of psychophysical development is a specialty of special pedagogy, but in the context of the development of inclusive education, it becomes important for general pedagogy. The article deals with the peculiarities of teaching children with mental disorders, as well as the importance of teaching mathematics of junior pupils for the development of their cognitive activity and further socialization. The effective methods and techniques for teaching children with autism spectrum disorders in mathematics (activation of cognitive activity, use of didactic games) were formulated. The effectiveness of the program for correction of cognitive activity of children with difficulty in learning in mathematics lessons in junior classes was developed and experimentally proved. The perspectives of the proposed program in secondary schools during the organization of inclusive education were outlined.

Key words: mental disorders, autism spectrum disorders, cognitive activity, mathematical knowledge, didactic game.

Закріплення на державному рівні інклюзивної освіти й активне впровадження ії засад у навчально-виховний процес вимагає суттєвих змін у підходах до змісту й організацій навчання, увикористаннідидактичнихметодів і прийомів. Головним завданням інклюзивної освіти є надання рівних можливостей отримання освіти всім особам, незважаючи на їх фрізичні та психологічні особливості. Безпосередньо процес навчання повинен бути побудований з урахуванням особливостей кожного з його учасників. Вітчизняні та зарубіжні фрахівці до ментальних порушень відносять порушення інтелектуальної, психоемоційної та психічної сорери, а також труднощі у навчанні та розлади аутичного спектра. Навчання дітей з особливостями психосрізичного розвитку - царина спеціальної педагогіки, але в умовах розвитку інклюзивного навчання набуває значущості для загальної педагогіки. У статті розкриті питання особливості навчання дітей із ментальними порушеннями, а також навчання математики молодших школярів для розвитку їх пізнавальної активності та подальшої соціалізації, сфоормульовані ефрективні методи та прийоми навчання дітей із розладами аутичного спектра математики (активізація пізнавальної активності, використання дидактичних ігор), розроблена й експериментально доведена ефективність програми корекції пізнавальної активності дітей із труднощами у навчанні на уроках математики у молодших класах, окреслені перспективи використання запропоновано програми у загальноосвітніх закладах під час організації інклюзивного навчання.

Ключові слова: ментальні порушення, розлади аутичного спектра, пізнавальна активність, математичні знання, дидактична гра.

Закрепление на государственном уровне инклюзивного образования и активное внедрение его принципов в учебно-воспитательный процесс требуют существенной модернизации образовательной системы в целом, изменений в организации обучения, использовании дидактических методов и приемов. Главной задачей инклюзивного образования является предоставление равных возможностей получения образовательных услуг всем лицам, несмотря на их фризические и психологические особенности. Процесс обучения должен быть построен с учетом особенностей каждого из его участников. Обучение детей с особенностями психофизического развития - область специальной педагогики, но в условиях развития инклюзивного образования приобретает значимость и для общей педагогики. $B$ статье раскрыты основные особенности обучения детей с ментальными нарушениями, обучения математике младших школьников для развития их познавательной активности и дальнейшей социализации, сформулированы методы и приемы обучения детей с расстройствами аутистического спектра математике (активизация познавательной активности, использование дидактических игр), разработана и экспериментально доказана эфрорективность программы коррекции познавательной активности детей с трудностями в обучении на уроках математики в младших классах, очерчены перспективы использования предложенной программы в общеобразовательных учреждениях при организации инклюзивного обучения.

Ключевые слова: ментальные нарушения, расстройства аутического спектра, познавательная активность, математические знания, дидактическая игра.

\section{Introduction}

The development of an inclusive approach to the education and upbringing of children with mental disorders is considered by the United Nations (UN), UNESCO and other international organizations as a priority direction for the development of national 
school education systems, as the implementation of the right of citizens to receive quality education and social integration is an important factor for sustainable development of society.

Inclusive education is a term used to describe the process of teaching children with special needs and violations of the mental sphere including those found in in public secondary schools schools. Under mental disorders we mean violations of the intellectual, psycho-emotional and psychic sphere, as well as children with learning difficulties and disorders of the autistic spectrum which negatively affects students' ability to study). Modern pedagogical practice faces the serious problem of including all children in the process of education and upbringing.

The process of teaching children with mental disorders is somewhat different from the process of teaching children with generally accepted norms of psychophysical development. Such children are able to master material at the level of pupils of junior high school. This determines certain peculiarities of the organization of teaching children with mental disorders, namely, they should only take place under conditions of specially organized education and with the presence of a permanent targeted influence from a special teacher. Teaching mathematics with children with thematic violations is one of the most difficult in special pedagogy, because the system of mathematical knowledge is based on the sufficient development of such mental processes as analysis, synthesis, generalization, abstraction, etc., which are the most damaged in them.

The analysis of scientific developments and studies made it possible to state the increasing attention of scientists to the problem of teaching children with mental disorders in the conditions of an incusion (A Beloshista, O. Gavrilov, N. Gladchenko, N. Sokolova, M. Sheremet).

The results of psychological and pedagogical research (T. Aliysheva, L. Akatova, N. Korokolta, and others), as well as the practice of teaching children with mental disorders, indicate that mathematics is particularly difficult to give them in the initial period of study. These difficulties are explained both by the specifics of the subject itself and by the peculiarities of the cognitive activity of children of this category. The peculiarities of teaching mathematics to children with intellectual disabilities both in the theoretical and in the practical terms are revealed in the works of L. Vavina, A. Vysotskaya, V. Zhuk, A. Khilko and others. In their studies, they indicate that persistent violations of the higher mental functions that are observed in mental disorders, prevent children from mastering the program material in mathematics in the amount provided by the requirements of the general school. Such students have peculiarities of mental activity, such as the inertia of formed links, slowness, fragmentation, lack of differentiation in the perception of material, etc. At the same time, children's studying mathematics is an important task on the way of socialization in the future of adult life. During the period of study, they must acquire such knowledge in mathematics that they would allow them to operate freely with arithmetical terms, carry out calculations, measurements, calculations, perform various operations with numerical values, solve problems.

Summing up the experience of Ukrainian scholars, we came to the conclusion that it is very important, before studying the process of transfer of knowledge, to thoroughly explore the cognitive abilities of children. When conducting the examination of children with mental disorders, it is necessary first of all to study in detail the structure of cognitive activity (the state of development of memory, thinking, perception, attention), to determine the ways of correction of violations and to draw up a plan for further work.

Experimental confirmation of our hypothesis that the correction of the cognitive activity of children with learning difficulties in mathematics lessons by means of didactic games is a prerequisite for increasing the level of assimilation of mathematical knowledge, the ability to use them in real life, and also contributes to the success of mastering new knowledge and socialization of such children, in the first stage, involves the justification and development of the method of conducting the experiment. At the next stage, criteria and indicators for assessing the level of formation in students with mental disorders of cognitive activity were determined.

The method of diagnosing the level of formation of cognitive activity is to clarify the ability and the willingness of children in this category to independently learn and understand the content of the proposed tasks aimed at activating cognitive activity (the method "Recognition of Figures" by R. Nemov, the method "Raven Matrix", the method "Small House" ("Budynochok") by N. Gutkina).

Correction of cognitive activity of students of the experimental group took place during the lessons of mathematics and provided for the additional use of three didactic games.

2 Diagnosis of the level of development of cognitive activity of children with learning difficulties

The empirical object of the study was students of grades 2 and 3 with a mild mental retardation of the Municipal Institution "Kharkiv Special Secondary School № 3" of the Kharkiv Regional Council and the Municipal Institution "Special Educational Complex of I-II Grades № 2" of Kharkiv Regional Council with a total number of research participants being 40 .

In our study, children were divided into control and experimental groups. The control and experimental group includes 20 children each.

The study was conducted on the following indicators: examination of the state of memory, thinking, attention, perception. 
The results of the indicators of the states of the cognitive components, we interpreted according to the levels (Table 1 ).

To diagnose the state of memory of younger schoolchildren with mental disorders, we used the adapted method "Identification of Figures" by R. Nemov (Nemov R.S., 2001).

The children were offered a table of the size of $50 \times 50 \mathrm{~cm}$ with 9 geometric figures, the time of exposure -15 seconds. They need to remember the figures. Immediately after the show, they need to strike out the nine figures which were perviously shown in table, which are among the other 24 figures $(10 \mathrm{x}$ $10 \mathrm{~cm}$ ). In order to complete the assignment, they gave the child an instruction to the task.

After completing the task, we noted and counted the number of correctly and incorrectly identified figures. In order to characterize the level of recognition, we calculated its coefficient $H: H=(R: 9)+W$, where $\mathrm{R}$ is the number of correctly identified figures; $\mathrm{W}$ is the number of incorrectly identified figures.

The most optimal recognition rate is one, so the closer the results of a particular subject to one, the better the child's processes of recognition of visual material work.

In order to diagnose the development of the thinking of junior schoolchildren with mild mental retardation, we used the adapted technique "Raven Matrix" (Galyan I., 2011). This technique is intended for evaluation of visual thinking among junior pupils. Here under the visual-figurative thinking is meant the ability to operate with different images and visual representations when solving problems.

Its essence was that the child was offered a series of ten detailed tasks of the same type, which gradually became more difficult. After studying the struc- ture of a large matrix, the child had to specify one of the details (of the eight available) that best suits this particular matrix, that is, it corresponds to its drawing or the logic of the location of its parts vertically and horizontally. To complete the task, the child was given instructions to task. Test time is 10 minutes.

At the end of the experiment, the experiment stopped and determined the number of matrices that were correctly resolved, as well as the total amount of points scored by the child for their solution. Each correctly solved matrix was evaluated in 1 point.

The next step is to diagnose attention. We used the methodology of N. Hutkina's "Small House" (Galyan I., 2011) to diagnose children of junior school age with mental disorders. The "Small House" test is a modification of the test of $D$. Wexler and is used to determine the level of mental development. We used this technique to study the productivity and stability of attention.

The tasks were aimed at revealing the child's ability to use the model, the ability to accurately copy it, navigate in their work. This makes it possible to find out the peculiarities of the development of arbitrary attention, spatial perception, sensory motor coordination and fine motor motility of the hand. The child is given instructions again. Runtime is 3 minutes.

The processing of the experimental material was carried out by counting the points awarded for errors.

The list of errors included such components as the absence of any detail of the drawing were considered, the increase of individual details of the picture more than twice, with a relatively correct preservation of the size of the whole picture, incorrectly depicted element, incorrect location of parts in space, deviation of straight lines by more than $30^{\circ}$ from a given direction, gaps between lines in those places where they should be connected, error-free copying.

Table 1

Indicators of the States of Cognitive Processes

\begin{tabular}{|c|l|l|l|}
\hline \multirow{2}{*}{ Indicator } & \multicolumn{2}{|c|}{ Level } \\
\cline { 2 - 4 } Memory & $\begin{array}{l}\text { 1 point (the child recognized } \\
\text { and remembered 8-9 figures, } \\
\text { immediately after the show, } \\
\text { struck out in the corresponding } \\
\text { form seen in the table 9 figures) }\end{array}$ & $\begin{array}{l}\text { 2-5 points (the child recog- } \\
\text { nized and remembered only } \\
\text { part of the figures shown, was } \\
\text { able to delete them in the } \\
\text { appropriate form) }\end{array}$ & $\begin{array}{l}\text { 6-9 points (the child did not } \\
\text { recognize and did not remem- } \\
\text { ber any of the presented } \\
\text { figures) }\end{array}$ \\
\hline \multirow{5}{*}{ Thinking } & $\begin{array}{l}\text { 7-10 points (the child accepts } \\
\text { the task, selects the neces- } \\
\text { sary elements for all proposed } \\
\text { matrices) }\end{array}$ & $\begin{array}{l}\text { 2-6 points (the child accepts } \\
\text { the task, selects only a part of } \\
\text { the necessary elements to the } \\
\text { proposed matrix) }\end{array}$ & $\begin{array}{l}\text { 0-1 point (the child accepts the } \\
\text { task, but does not perform it) }\end{array}$ \\
\hline Attention & $\begin{array}{l}\text { 0 point (any attention is well } \\
\text { developed, and such compo- } \\
\text { nents as concentration, produc- } \\
\text { tivity and stability arevery high) }\end{array}$ & $\begin{array}{l}\text { 1-2 points (the average devel- } \\
\text { opment of arbitrary attention, } \\
\text { and components such as } \\
\text { concentration, productivity and } \\
\text { sustainability of attention at the } \\
\text { average level) }\end{array}$ & $\begin{array}{l}\text { more than 4 points (low } \\
\text { development of arbitrary atten- } \\
\text { tion, as well as concentration, } \\
\text { productivity and stability of } \\
\text { attention at a low level) }\end{array}$ \\
\hline Perception & $\begin{array}{l}\text { 8-10 points (the child correctly } \\
\text { identified 14 items in 21-30 } \\
\text { seconds) }\end{array}$ & $\begin{array}{l}\text { 4-7 points (the child found all } \\
\text { the necessary items in 31-50 } \\
\text { seconds) }\end{array}$ & $\begin{array}{l}\text { 1-3 points (more than 1 } \\
\text { minute, the child could not } \\
\text { name all the hidden objects) }\end{array}$ \\
\hline
\end{tabular}


To survey the state of development of perception among junior schoolchildren with mental disorders, we used the technique of R. Nemov, "What objects are hidden in the drawings?". We offered each child 3 pictures and provided them with instructions. Runtime was 1 minute for each picture.

If the child was in a hurry, without finding all the objects in one picture, we immediately proceeded to the next, and in the end they returned the child to work on the previous image.

After analyzing the obtained indicators of the development of cognitive activity of children with mental disorders, it was concluded that children have a low level of development of cognitive components (insufficient attention, memory, underdevelopment, and thinking). According to our data, $12.5 \%$ of children are at high levels, $47.2 \%$ of children have an average level of development of cognitive components and $40.3 \%$ of children are at a low level. Because of the organic or functional disturbances that occur, children have virtually no imagination. Structural and operational components of the imagination in them are not formed, imagination in relation to thinking performs a compensatory function. Children can not use memory images, perceptions, suffer the integrity of creating images. A significant difficulty is their understanding of the condition and content in the memory of the verbal task.

3 Model of the corrective program for the development of cognitive activity of children with learning difficulties in mathematics lessons

Solving the problem of developing cognitive activity of mentally retarded junior pupils in mathematics lessons depends to a large extent on the effective implementation of correctional and developmental work.

We believe that one of the means of correction of cognitive activity is the mathematics lessons that introduce special methods and techniques of work, the main and main of which is the didactic game.

It should be noted that the didactic game helps in solving cognitive tasks in a lesson put in an interesting form. It is the decision of the cognitive problem associated with mental stress, overcoming the difficulties that accustomed the child to mental work. Assimilating or clarifying one or another educational material in a corrective-developing game, children learn to observe, analyze, compare, classify objects on some grounds; develop memory, attention, perception.

To carry out the tasks of the experiment, a system of didactic games for children with mild mental retardation of elementary school age was selected and included in mathematics lessons in order to develop the cognitive activity of children of the specified category.

The purpose of this stage of the study was to substantiate, develop and experimentally verify the means and methods of corrective work on the devel- opment of cognitive activity of mentally retarded junior pupils in mathematics lessons.

In accordance with the stated goal, the task were outlined:

- to identify trends and stages of corrective work;

- to develop and test the system of didactic games that was used in mathematics lessons for the development of cognitive activity of mentally retarded junior pupils;

- to conduct a comparative analysis of the results.

- to analyze the effectiveness of the developed correction system.

A selection of didactic games of mathematical focus was directed at the correction and development of all components of cognitive activity of junior pupils: perception, memory, thinking, attention.

Didactic games were included in each lesson of mathematics and at different stages of the educational process: when explaining the new educational material, when learning and fixing the educational material, with the repetition of the studied material.

In each lesson of mathematics, we included 3 didactic games that simultaneously had to affect all cognitive components.

The structure of the lesson in mathematics was as follows:

- organization of pupils for a lesson (at this stage, the working environment for effective work was created, checks were made for manuals, office supplies and the preparation, switching of pupils from the activities they were engaged at the break (or before it began) on the educational process);

- nervous-psychological preparation (NPP) - the use of correctional means, which allows students to calm down from nervous excitement and focus on the teacher);

- checking the homework (at this stage, the homework done by the students was checked);

- posting the subject, goals and tasks of the lesson;

- propedeutic part (at this stage the knowledge and methods of action were renewed, the links were established between the old and the new material, the students were introduced into the circle of concepts and ideas that are the basis for better perception of the new one);

- formation part (depended on the stage of educational work: explanation of new material, consolidation of the already studied, verification of acquired knowledge);

- physical education minute;

- summaries and evaluation (the work of each child was analyzed at the lesson, after which an assessment was made);

- instruction on the fulfillment of the homework (explanation of the algorithm of the homework);

- relaxation (relaxation of the organism, switching activities); 
- tidying the working places.

Consequently, the next stage of the study envisaged the development of a series of corrective lessons in mathematics, each of which included 3 teaching games for the development of all components of cognitive activity, namely: perception, memory, thinking, attention. At all stages of the educational process during the lesson of mathematics, didactic games on correction of perception were aimed at:

- clarification of visual, auditory, tactile, motor sensations:

- development of purposeful perception of color, form, size, material and quality of the object;

- training to relate objects by size, form, color, visually checking their choices;

- differentiation of the perception of objects by color, size and form;

- development of audio and visual perception;

- increase of volume of visual, auditory, tactile representations;

- formation of tactile differentiation of the properties of objects;

- development of tactile-motor perception;

- increase of field of view, speed of examination;

- formation of the integrity of the perception of the image of the subject;

- training to analyze the whole of its component parts;

- development of visual analysis and synthesis;

- development of the ability to generalize objects by features (color, form, value);

- development of perception of the spatial arrangement of objects and their parts;

- development of visual-motor coordination (Beloshistaya A.V., 2002)

- Instead, correction and memory training didactic games included the following goals:

- development of motor, verbal, figurative, verbal-logical memory;

- learning knowledge through arbitrary, conscious memorization;

- development of speed, completeness, accuracy of reproduction;

- formation of the completeness of the reproduction of verbal material (to reproduce verbal material in close proximity to the text) (Gavrylov O.V, Lyashenko O.M., Korolko N.I., 2006);

- improving the accuracy of reproduction of verbal material (correctness of the wording, ability to give a short answer);

- improving the consistency of memory, the ability to establish causal and temporal relationships between individual facts and phenomena;

- an increase in memory (Beloshistaya A.V., 2002).

Regarding the correction and development of thinking, at various stages of the educational process, the didactic games that were included in the mathematics lessons were aimed at:
- development of visually-effective, visualfigurative and logical thinking;

- development of the ability to analyze, compare, generalize, classify, and systematize on the visual and verbal basis;

- learning to distribute the main, essential;

- learning to compare, to find a similarity and distinction of features and concepts.

Didactic games for the development of mental operations analysis and synthesis were envisaged (Illyashenko T.D., 2003):

learning to group objects;

- development of the ability to understand the relationship of events and to build sequential solutions, to establish the causal - consequential relationships;

- intensification of creative cognitive activities;

- development of the critical thinking (objective evaluation of oneself and others).

Also, having analyzed the peculiarities of the attention of children with mental disorders of junior school age, we offered didactic games for its correction, which included the following goals (Beloshistaya A.V., 2002):

- development of the ability to concentrate attention (degree of concentration of attention on the object):

- development of sustainability attention (longterm focus on the object);

- development of the ability to switch attention (deliberate, conscious transfer of attention from one object to another);

- development of the ability to distribute the attention (the possibility to hold in the field of attention simultaneously several objects);

- increase in the amount of attention (the number of objects that can be covered by the child at the same time);

- formation of a targeted focus (directed in accordance with the set task);

- development of a arbitrary attention (requires a volitional effort);

- activation and development of the sight and auditory attention (Zinchenko S.M., 2004).

For more effective correction and development work on the development of cognitive activity of children of this category, we systematized the lessons in the stages of the educational process and for each such stage we selected 3 lessons, each of which included 3 didactic games.

After conducting purposeful systematic correction-development work with this group on the formation and development of cognitive structures, we observed a positive dynamics of change.

In particular, the following indicators of the following criteria have increased in children:

The state of thinking, namely: in the experimental group, the development of visually effective, visual 
and figurative thinking and logical thinking improved, and children at the end of the study could operate not with concrete images, but by abstract concepts, expressed words, they also began to analyze and compare information, draw conclusions;

The state of attention - the quality of spontaneous and voluntary attention has increased and the performance of children's attention in improving the performance of tasks has been determined, attention has become more concentrated and focused;

Memory status - children of the experimental group increased the volume of auditory and visual memory, as well as the productivity of spontaneous and arbitrary types of memory in performing tasks of different levels;

State of perception - it was found that children perceive geometric figures, numbers, elementary examples, problems, spectral scale and physical quantities.

During the secondary diagnosis, the improvement of the indicators from all the evaluation criteria was found, namely: the "Thinking state" criterion in children improved the indicators of visual-thinking thinking, and the criterion "Attention" was diagnosed with an increase in the quality of any attention during the performance of tasks and a positive the dynamics of the formation and development of cognitive structures in junior schoolchildren with mental disorders.

Consequently, the repeated diagnosis has shown that the use of didactic games in mathematics lessons for the development of components of cognitive activity is effective, since in children of the experimental group, the indicators, compared with the primary diagnosis, increased significantly.

\section{Conclusions}

The purpose of this article was to formulate the peculiarities of the cognitive sphere of children with learning difficulties, to identify ways of activating thinking, memory, attention, perception, experimentally check the effectiveness of the use of didactic games in mathematics lessons for the education of children with mental disorders, and outline the prospects for further implementation of the proposed correction program intensification of cognitive processes of children with autism spectrum disorders. It was found that didactic games should be accessible and understandable to children, consistent with their age and psychological peculiarities, and therefore each didactic game should have its own specific educational and corrective goal. It should be noted that during the implementation of the tasks of each game for better perception of information several different analyzers should be involved at a time.

Correctional value of game techniques and techniques is that they develop mental activity and cognitive interests of children, contribute to the conscious perception of educational material, the sustainability of actions in one direction, the formation of positive motivation for learning and the sense of success, develop autonomy, as well as memory, attention and logical thinking.

The validity of the assertions of the proposed study was proved empirically, which makes it possible to assert the importance of forming, in children with mental disorders, mathematical knowledge, abilities, skills and the effectiveness of using during this process of didactic games.

The approval of the development of inclusive education at the legislative level and the active realization of its tasks in practice, allows using the proposed program of correction of cognitive processes not only in special institutions, but also during the development of an individual program for teaching a child with peculiarities of psychophysical development and in mathematics classes in inclusive classes.

The analysis of the psychological characteristics of children of elementary school age provides an opportunity to state that one of the factors of the child's readiness for school is the transition from the game to the educational activity. As the leading activities of junior pupils are not yet fully equipped and have many features of the game, the feasibility of using didactic games in the training becomes even more relevant. This is especially true for children whose activities retain many features of gaming activity and have difficulty in learning, in organizing which we should remember that in such a situation it is advisable to use methods and techniques of preschool teaching methods for children. It is known that the game is the main method of teaching children of preschool age, it is not only effective, but also interesting for children, allows them to learn the educational material in a child-friendly form. Younger students are also pleased to perceive the use of didactic games during the organization of the educational process, which makes it possible to turn a simple lesson into a fun and cognitive event. All of the above, in our opinion, outlines the further perspectives of the described research, especially in the context of the development of inclusive education, when simultaneously it is necessary to teach children not only with different physical, psychological and cognitive characteristics, but also children with different types of conducting activities.

\section{REFERENCES:}

1. Акатов Л.И. Социальная реабилитация детей с ограниченными возможностями здоровья. Психологические основы : учебное пособие. Москва : ВЛАДОС, 2003. 368 с.

2. Дети с ограниченными возможностями: проблемы и инновационные тенденции в обучении и воспитании : хрестоматия / сост. Н.Д. Соколова. Москва : ГНОМ и Д, 2001. 448 с.

3. Вдовиченко І.В., Трачук І.М. Спілкування дошкільників 3 інтелектуальною недостатністю в умовах дитячого будинку. Науковий часопис Наці- 
онального педагогічного університету імені М.П. Драгоманова. Серія 19 : Корекційна педагогіка та психологія. Київ : НПУ, 2007. Вип. 7. C. $97-98$.

4. Гладченко І.В. Основні напрямки корекційно-виховної та соціально-абілітаційної діяльності педагога-десектолога в спеціалізованих дитячих будинках. Актуальні проблеми навчання дітей 3 особливими потребами : збірник наукових праць Університету «Україна». 2010. С. 279-285.

5. Алышева Т.В. Технология фрормирования понятия числа у учащихся подготовительного - первого классов специальной (коррекционной) общеобразовательной школы У111 вида. Организация и содержание образования детей с нарушениями раз- вития : Материалы Международной научно-практической коноеренции. Ч. 1. Москва, 2008.

6. Діти 3 особливими потребами у початковійшколі: поради батькам. Кн. 3 / Л.С. Вавіна, А.М. Висоцька, В.В. Жук та ін. ; за ред. В.І. Бондаря, В.В. Засенка. Київ : Науковий світ, 2006. 212 с.

7. Кузьмина-Сыромятникова Н.Ф. Методика арифметики во вспомогательной школе. Москва : Учпедгиз, 1949.

8. Матасов Ю.Т. Особенности восприятия и понимания основ наглядной геометрии учениками младших классов вспомогательной школы. Дефектология. 1975.

9. Мершон Б.Л., Хилько А.А. Некоторые вопросы методики преподавания арифрметики во вспомогательной школе. Москва : Просвещение, 1968. 